\title{
Green open spaces in the perspective of ecosystem services (a case study of green open spaces in the urban area of Yogyakarta)
}

\author{
Giska Parwa Manikasari ${ }^{1, *}$, Lutfi Muta'ali' ${ }^{2}$, and Lies Rahayu \\ Faida $^{3}$
}

1 Vocational College Universitas Gadjah Mada Sekip Unit II, Depok, Sleman, Indonesia 55281

2 Faculty of Geography Universitas Gadjah Mada Sekip Utara, Bulaksumur, Sleman, Indonesia 55281

3 Faculty of Forestry Universitas Gadjah Mada Jl. Agro No.1, Bulaksumur, Sleman, Indonesia 55281

*e-mail: giska.parwa.m@mail.ugm.ac.id

\begin{abstract}
Green Open Spaces (GOS) have a variety of ecosystem services which can be utilized by society. This study aims to identify criteria for determining ecosystem services in GOS, to study the conditions and distributions of potential ecosystem services in the Urban Area of Yogyakarta (UAY)'s GOS, and optimize the existing ecosystem services in GOS. The research's locations include GOS in UAY consisting of urban forests, city parks, riverbanks, and greenbelts, for a total of twelve research locations. The identification of the criteria for GOS was accomplished with the expert opinion and comparative methods resulting in weight values. The field data and expert assessments were analyzed through a scoring analysis to quantify the level of ecosystem services in each research location. This data was further analyzed by examining the area allotments within the existing regulatory framework to the determine the conditions of GOS with optimal ecosystem services. The results of the study show that each of the sixteen examined criteria plays a role in ecosystem services. The values of ecosystem services of GOS in UAY show different values for each type of GOS. In general, the ecosystem services in urban forests are rated favourably in each category, while city parks and riverbanks moderate ratings, and greenbelts have the lowest average performance of any GOS. Based on the results, optimizing ecosystem services in UAY's GOS can be accomplished by strengthening their performance in each criterion with the most attention paid to each GOS's allotment type.
\end{abstract}

\section{Keywords}

Citation: Manikasari, G. P., Muta'ali, L. \& Faida, L. R. (2018). Green open spaces in the perspective of ecosystem services (a case study of green open spaces in the urban area of Yogyakarta). In T. R. Nuringtyas, A. C. Sukartiko, \& A. Isnansetyo (Eds.), UGM Digital Press Life Sciences: Vol. 1. Proceeding of the 2nd International Conference on Tropical Agriculture, (pp. 31-38).

Published: October, 2018 city park, ecosystem services, greenbelt, green open spaces, riverbank, urban forest.

\section{Introduction}

The city of Yogyakarta, famous for its status as a cultural hub, government centre, tourism destination and education centre, is constantly evolving. This continuous development is affecting the surrounding areas of Yogyakarta and these areas are subject to heavy 
urban influence. Yogyakarta's high-intensity development is facing a land scarcity issue which restricts the amount of land available for meeting the demands of urban life. Yogyakarta's development has physically affected the adjacent areas of Bantul and Sleman, which used to be considered rural areas. According to Yogyakarta Special Region Province Regional Regulation Number 22010 regarding city planning, the suburban areas of Yogyakarta city are recognized as part of the Yogyakarta municipal area (UAY) which will become strategic areas as they are integrated into the city. These integrated areas include Yogyakarta City and parts of Ngaglik District, Mlati District, Godean District, Gamping District, Ngemplak District, Kasihan District, Sewon District, and Banguntapan District. The Yogyakarta proper has been designated as national activity centre, national and regional strategic area, education centre, goods and services hub and tourism destination has contributed to Yogyakarta's urban development and has resulted in Yogyakarta's land use being dominated by residential areas, services, cottage industries, and trading sectors.

The development taking place in urban Yogyakarta is inevitable. Urban environments typically develop economically but with little regard to ecological factors. This results in the disruption of urban ecosystems, which causes various forms of ecological instability such as pollution. One proposed solution for reducing the impact of ecological instability in urban areas is the utilization of Green Open Space (GOS) in urban landscapes in compliance with the Regulation of the Minister of Home Affairs (Permendagri) Number 12007 on Planning of Green Open Space for Urban Areas. At the Earth Summits in Rio de Janeiro, Brazil (1992) and Johannesburg, South Africa (2002), scientists agreed that the proportion of green open space in the urban areas should be at least 30 (thirty) percent of a town's total area and this statement was written by Law Number 26 Year 2007 on Spatial Planning. However, the measurement of Green Open Space (GOS) proportions have only been classified based on the status of the region, and not on the form or structure of the vegetation [1]. Discussions on urban green open spaces also tend to be in quantity, while ignoring quality [2]. Furthermore, the arrangement of elements in a constructed urban environment which are not consistent with the development and changes in a city's structure and zoning can lead to a decline in environmental quality [3]. These conditions necessitate research on the quality of ecosystem services in green open spaces to determine a set of recommended criteria for an ideal green open space in urban Yogyakarta.

Based on the introduction above, the following objectives have been established. 1) Identifying the criteria of Green Open Space when evaluating potential ecosystem services. 2) Examining the conditions of ecosystem services in Green Open Spaces in urban Yogyakarta, and 3) to optimize the Green Open Spaces in urban Yogyakarta through the perspective of ecosystem services.

\section{Methods}

\subsection{Research Locations}

The research was conducted at the Public Green Open Space in Urban Areas of Yogyakarta, which is separated into four forms of green open space in the form of urban forests, parks, green belts, and river borders. The determination of research locations was based on a census referring to the locations which has been designated as areas of green open space by the Municipal/Regency Government according to information provided by Environmental Agency (BLH) of the Special Region of Yogyakarta (DIY), as the determination of research samples for road green belt areas was conducted by utilizing purposive sampling based on the location with the highest vehicle density in Yogyakarta Urban Areas referring to the information the Department of Transportation, Communication, and Information of Yogyakarta Provincial Government, which was defined to be 12 observation sites.

\subsection{Research Instruments and Materials}

These were the research instruments utilized for data collection in the field, such as GPS (Global Positioning System), a questionnaire on criteria for green open space in the perspective of ecosystem services, stationery, computers, and documentation tools.

The materials required in this research include Map of the Study location in 2016 with a map scale of 1:120.000 and the source was the thematic base map of Special Region of Yogyakarta as well as the areas 
of Green Open Space in Yogyakarta Urban Areas containing urban forests, parks, green belt, and river border from google earth software.

\subsection{Types of Collected Data}

Data types necessary for this research include primary data and secondary data. The primary data required includes the types of green open space, canopy stratum, canopy cover, coverage of the groundcover plants, the number of tree species, the presence of local species, the presence of identity species of Urban Area of Yogyakarta, presence of flowering trees, presence of fruit trees, the presence of species of $\mathrm{Pb}$-absorbing trees, the presence of rare and protected species, the presence of water storage tree species, the presence of species of birds, colors, and sounds in Green Open space in Yogyakarta Urban Areas. Secondary data collected includes spatial data indicating distributions of Green Open Space in Yogyakarta Urban Areas.

\subsection{Methods of Data Collections and Analyses}

Research variables and methods used in the Green Open Space research in the perspective of ecosystem services is presented in Table 1.

Table 1 Summary of research variables and methods

\begin{tabular}{|c|c|c|c|c|c|}
\hline No & Objectives & Data & $\begin{array}{l}\text { Methods of Data } \\
\text { Collection }\end{array}$ & $\begin{array}{l}\text { Methods of } \\
\text { Data Analyses }\end{array}$ & Results \\
\hline 1 & $\begin{array}{l}\text { To identify the criteria of } \\
\text { Green Open Space in the } \\
\text { determination of } \\
\text { ecosystem services. }\end{array}$ & $\begin{array}{l}\text { Criteria for Green } \\
\text { Open Space }\end{array}$ & $\begin{array}{l}\text { Expert-based } \\
\text { valuation and } \\
\text { Snowball } \\
\text { sampling }\end{array}$ & $\begin{array}{l}\text { Pairwise } \\
\text { comparison }\end{array}$ & $\begin{array}{l}\text { Weight values from } \\
\text { each criterion }\end{array}$ \\
\hline 2 & $\begin{array}{l}\text { To carry out studies on } \\
\text { the ecosystem services } \\
\text { condition of Green Open } \\
\text { Space in Yogyakarta } \\
\text { Urban Areas. }\end{array}$ & $\begin{array}{l}\text { Green Open Space } \\
\text { in Yogyakarta } \\
\text { Urban Areas } \\
\text { including urban } \\
\text { forests, parks, } \\
\text { green belts, river } \\
\text { borders. }\end{array}$ & $\begin{array}{l}\text { Purposive } \\
\text { sampling }\end{array}$ & Scoring & $\begin{array}{l}\text { The condition of Green } \\
\text { Open Space in } \\
\text { Yogyakarta Urban } \\
\text { Areas in perspective of } \\
\text { ecosystem services in } \\
\text { form of maps and tables }\end{array}$ \\
\hline 3 & $\begin{array}{l}\text { To optimize the Green } \\
\text { Open Space in Yogyakarta } \\
\text { Urban Areas in } \\
\text { perspective of ecosystem } \\
\text { services. }\end{array}$ & $\begin{array}{l}\text { The condition of } \\
\text { Green Open Space } \\
\text { in Yogyakarta } \\
\text { Urban Areas in } \\
\text { perspective of } \\
\text { ecosystem }\end{array}$ & & $\begin{array}{l}\text { Deductive } \\
\text { descriptive }\end{array}$ & $\begin{array}{l}\text { Suitable criteria } \\
\text { recommendation for } \\
\text { Green Open Space in } \\
\text { order to optimize the } \\
\text { ecosystem services of } \\
\text { the Green Open Space }\end{array}$ \\
\hline
\end{tabular}

There are eight experts were involved in the valuation who include Forestry experts ( 3 persons), Biology experts (2 persons), Environmental experts (2 persons), and representatives from the Environmental Agency (BLH) of the Special Region of Yogyakarta (1 person). All results and answers or judgments from the experts are then processed with pairwise comparison method.

\section{Results and Discussions}

\subsection{Identification of Criteria for Green Open Space in the Determination of Ecosystem Services}

Criteria for green open space covering types of green open space, canopy stratum, canopy cover, coverage of groundcover plants, the number of tree species, the presence of local species, the presence of identity species of Urban Area of Yogyakarta, presence of flowering trees, presence of fruit trees, the presence of species of $\mathrm{Pb}$-absorbing trees, the presence of rare and protected species, the presence of water storage tree species, the presence of species of birds, colors, and sounds, and the facilities play different roles to the eleven selected ecosystem services. 
Table 2 Level of criteria roles of green open space towards ecosystem services

\begin{tabular}{|c|c|c|c|c|c|c|c|c|c|c|c|}
\hline \multirow{2}{*}{$\begin{array}{l}\text { Criteria and } \\
\text { Ecosystem } \\
\text { Service Types }\end{array}$} & \multicolumn{3}{|c|}{ Provisioning } & \multicolumn{2}{|c|}{ Regulating } & \multicolumn{4}{|l|}{ Cultural } & \multicolumn{2}{|c|}{ Supporting } \\
\hline & Food & $\begin{array}{l}\text { Fresh } \\
\text { Water }\end{array}$ & $\begin{array}{l}\text { Wood } \\
\text { and } \\
\text { Fiber }\end{array}$ & Climate & $\begin{array}{l}\text { Fresh } \\
\text { Air }\end{array}$ & Spiritual & Recreational & Aesthetic & Educational & $\begin{array}{l}\text { Nutrient } \\
\text { Cycling }\end{array}$ & Habitat \\
\hline $\begin{array}{l}\text { Types of Green } \\
\text { Open Space }\end{array}$ & 0.45 & 0.69 & 0.42 & 0.95 & 0.88 & 0.43 & 1.00 & 0.87 & 0.95 & 0.70 & 1.00 \\
\hline Canopy stratum & 0.44 & 0.45 & 0.60 & 0.68 & 1.00 & 0.27 & 0.47 & 0.91 & 0.82 & 0.96 & 0.59 \\
\hline Canopy cover & 0.55 & 0.83 & 0.77 & 1.00 & 0.91 & 0.47 & 0.79 & 0.75 & 0.89 & 1.00 & 0.76 \\
\hline $\begin{array}{l}\text { Groundcover } \\
\text { vegetation }\end{array}$ & 0.46 & 0.65 & 0.22 & 0.67 & 0.58 & 0.30 & 0.37 & 0.49 & 0.51 & 0.67 & 0.51 \\
\hline $\begin{array}{l}\text { The number of } \\
\text { tree species }\end{array}$ & 0.83 & 0.58 & 1.00 & 0.76 & 0.84 & 0.61 & 0.61 & 0.67 & 0.74 & 0.78 & $0, .66$ \\
\hline $\begin{array}{l}\text { The presence of } \\
\text { local species }\end{array}$ & 0.42 & 0.22 & 0.30 & 0.28 & 0.31 & 1.00 & 0.68 & 0.58 & 1.00 & 0.22 & 0.30 \\
\hline $\begin{array}{l}\text { The presence of } \\
\text { identity trees }\end{array}$ & 0.31 & 0.23 & 0.30 & 0.28 & 0.29 & 0.94 & 0.63 & 0.78 & 0.93 & 0.20 & 0.31 \\
\hline $\begin{array}{l}\text { The presence of } \\
\text { flowering trees }\end{array}$ & 0.54 & 0.16 & 0.29 & 0.22 & 0.30 & 0.38 & 0.52 & 1.00 & 0.52 & 0.30 & 0.49 \\
\hline $\begin{array}{l}\text { The presence of } \\
\text { fruit-bearing } \\
\text { trees }\end{array}$ & 1.00 & 0.18 & 0.29 & 0.23 & 0.26 & 0.30 & 0.29 & 0.43 & 0.47 & 0.24 & 0.51 \\
\hline $\begin{array}{l}\text { The presence of } \\
\text { high } \mathrm{Pb} \text { - } \\
\text { absorbing tree } \\
\text { species }\end{array}$ & 0.41 & 0.26 & 0.47 & 0.49 & 0.96 & 0.23 & 0.38 & 0.31 & 0.57 & 0.20 & 0.26 \\
\hline $\begin{array}{l}\text { The presence of } \\
\text { rare and } \\
\text { protected tree } \\
\text { species }\end{array}$ & 0.38 & 0.21 & 0.26 & 0.29 & 0.49 & 0.89 & 0.64 & 0.45 & 0.93 & 0.18 & 0.24 \\
\hline $\begin{array}{l}\text { The presence of } \\
\text { tree species } \\
\text { with a high } \\
\text { ability to store } \\
\text { water }\end{array}$ & 0.86 & 1.00 & 0.55 & 0.66 & 0.65 & 0.76 & 0.45 & 0.37 & 0.74 & 0.57 & 0.41 \\
\hline $\begin{array}{l}\text { The presence of } \\
\text { bird species }\end{array}$ & 0.42 & 0.23 & 0.28 & 0.28 & 0.29 & 0.42 & 0.68 & 0.59 & 0.91 & 0.24 & 0.58 \\
\hline $\begin{array}{l}\text { The color } \\
\text { compositions }\end{array}$ & 0.25 & 0.13 & 0.25 & 0.22 & 0.21 & 0.32 & 0.68 & 0.77 & 0.51 & 0.13 & 0.25 \\
\hline The voice & 0.19 & 0.13 & 0.22 & 0.18 & 0.33 & 0.34 & 0.55 & 0.48 & 0.41 & 0.12 & 0.21 \\
\hline The facilities & 0.11 & 0.11 & 0.13 & 0.18 & 0.14 & 0.23 & 0.65 & 0.75 & 0.52 & 0.09 & 0.09 \\
\hline
\end{tabular}

Value category: Very low $=0.00-0.10$ Low $=0.10-0.23$ Middle $=0.23-0.40$ High $=0.40-0.70$ Very high $=0.70-1.00$

The level of roles for each Green Open Space criterion against the 11 ecosystem services from Table 2 are described as follow:

a. Types of Green Open Space have a significant influence towards the cultural ecosystem service covering the services of recreation and ecotourism, education and science, as well as spiritual cultural ecosystem service; regulation ecosystem services including services of climate and clean air regulations; and habitat support ecosystem service.

b. Canopy stratum plays an indispensable role towards the climate regulation ecosystem service; cultural ecosystem service covering aesthetic ecosystem service as well as education and science services; and also nutrient cycling supporting ecosystem service.

c. Canopy cover plays a very important role towards supply ecosystem services involving clean water and wooden material provisions; regulating ecosystem services including services of climate and clean air regulations; cultural ecosystem service covering the services of recreation and ecotourism, education and science, and aesthetic cultural ecosystem service; as well as supporting ecosystem services consisting of nutrient cycling and habitat. 
d. The number of tree species plays a very significant role in the provisioning ecosystem services involving services of food and wooden materials; regulating ecosystem services including services of climate and clean air regulations; cultural ecosystem services covering education and science services; as well as supporting ecosystem service such as nutrient cycling.

e. The presence of local species plays a very important role in cultural ecosystem services covering education and science services, as well as spiritual cultural ecosystem services.

f. The presence of identity trees of Yogyakarta Urban Areas plays a significant role towards cultural ecosystem services covering education and science services, aesthetic cultural ecosystem services, and spiritual cultural ecosystem services.

g. The presence of flowering trees plays a very important role in aesthetic ecosystem services.

h. The presence of fruit-bearing trees plays a significant role in food provisioning ecosystem services.

i. The presence of high $\mathrm{Pb}$-absorbing tree species plays a very significant role towards the ecosystem service of clean air regulations.

j. The presence of rare and protected tree species plays a significant role in cultural ecosystem services of education and science, and spiritual cultural ecosystem services.

k. The presence of tree species with a high ability to store water plays a very important role in ecosystem services of clean water provisioning as well as cultural ecosystem services of education and science.

1. The presence of bird species plays a significantly high role in the cultural ecosystem services of education and knowledge.

$\mathrm{m}$. The colour compositions formed from vegetation associations and other physical environments play a very high role in aesthetic cultural ecosystem services.

n. The facilities featured in the Green Open Space play a very high role in aesthetic culture ecosystem services.

\subsection{Conditions and Distributions of Ecosystem Services Potential of Green Open Space in Yogyakarta Urban Areas.}

Green Open Space performs a function as the protection area for the ongoing functions of ecosystems and life supports. The existence of green open space in urban areas is very considerable to support the sustainability of an urban ecosystem. Green open space in Yogyakarta urban areas is expected to provide highly valuable ecosystem services to society. The ecosystem services meant are in the form of the provisioning services, regulating services, cultural services, and support services based on the value of each criterion of Green Open Space in Yogyakarta Urban Areas.

The value and distribution of the eleven ecosystem services under the eleven categories of ecosystem services for each observation spots of Green Open Space in Yogyakarta Urban Areas are presented in Table 3 below. 
Table 3 Value of ecosystem services of observation location of green open space on four main categories of ecosystem services

\begin{tabular}{|c|c|c|c|c|c|c|c|c|c|c|c|c|}
\hline \multirow{3}{*}{ No } & \multirow{3}{*}{ GOS } & \multicolumn{11}{|c|}{ Ecosystem Services Value } \\
\hline & & \multicolumn{3}{|c|}{ Provisioning } & \multicolumn{2}{|c|}{ Regulating } & \multicolumn{4}{|c|}{ Cultural } & \multicolumn{2}{|c|}{ Supporting } \\
\hline & & Food & $\begin{array}{l}\text { Fresh } \\
\text { Water }\end{array}$ & $\begin{array}{l}\text { Wood } \\
\text { and } \\
\text { Fiber }\end{array}$ & Climate & $\begin{array}{c}\text { Fresh } \\
\text { Air }\end{array}$ & Spiritual & Recreational & Aesthetic & Educational & $\begin{array}{l}\text { Nutrient } \\
\text { Cycling }\end{array}$ & Habitat \\
\hline 1 & Arboretum urban forest of Forestry Faculty & 418 & 428 & 416 & 426 & 414 & 410 & 406 & 406 & 408 & 446 & 432 \\
\hline 2 & Arboretum of Gembira Loka Zoo & 414 & 416 & 406 & 424 & 420 & 392 & 412 & 420 & 408 & 434 & 436 \\
\hline 3 & Denggung Park & 326 & 292 & 318 & 308 & 310 & 334 & 350 & 356 & 336 & 306 & 326 \\
\hline 4 & Gajah Wong Educational Park & 270 & 216 & 252 & 230 & 232 & 274 & 292 & 294 & 274 & 218 & 260 \\
\hline 5 & Lalu Lintas Park & 224 & 198 & 220 & 208 & 210 & 220 & 258 & 248 & 236 & 198 & 232 \\
\hline 6 & Code Riverbank & 372 & 348 & 368 & 342 & 344 & 344 & 338 & 348 & 340 & 356 & 354 \\
\hline 7 & Gajah Wong Riverbank & 344 & 296 & 334 & 292 & 306 & 318 & 302 & 312 & 306 & 304 & 316 \\
\hline 8 & Winongo Riverbank & 346 & 298 & 336 & 294 & 308 & 324 & 316 & 326 & 316 & 306 & 318 \\
\hline 10 & Green belts Perintis Kemerdekaan street & 100 & 100 & 100 & 100 & 100 & 100 & 100 & 100 & 100 & 100 & 100 \\
\hline 9 & Green belts in Magelang Street & 148 & 128 & 142 & 126 & 126 & 124 & 120 & 122 & 120 & 132 & 132 \\
\hline 11 & Green belts in Cik Ditiro Street & 100 & 100 & 100 & 100 & 100 & 100 & 100 & 100 & 100 & 100 & 100 \\
\hline 12 & Green belts in Malioboro Street & 108 & 108 & 110 & 108 & 106 & 124 & 114 & 116 & 116 & 106 & 108 \\
\hline
\end{tabular}

Table 3 shows that Green Open Space in Yogyakarta Urban Areas in form of Arboretum urban forest of Forestry Faculty and Arboretum of Gembira Loka Zoo possess a high ecosystem service value to the eleven categories of ecosystem services, meanwhile, the green open space of parks located in Denggung Park and Gajah Wong Educational Park have a moderate value of ecosystem value.

City forests have high category ecosystem services for the eleventh ecosystem services because the field conditions of the 16 Green Open Space criteria indicate ideal or maximum scores, ie 5, whereas green paths have low-value ecosystem services for the eleven ecosystem services under study has a field condition with a low score, ie one. Shapes of Green Open spaces that are clumped, multi-strata, canopy cover and lower plants are high, there are local type tree, type of identity of Yogyakarta Urban Area, flowering tree, fruit trees, presence of $\mathrm{Pb}$ absorbent tree species, rare and protected trees, bird species, color composition, and the presence of birds and insects from the Green Open Space of the Urban Area of Yogyakarta will form a Green Open Space area with a high value of ecosystem services.

\subsection{Optimization of Green Open Space in Yogyakarta Urban Areas in Perspective of Ecosystem Service}

Environment management is an integrated effort in utilizing, managing, preserving, supervising, controlling, restoring and developing the environment [4]. There are two forms of management of green open space by Jamil (2002) [5], the management of the landscape or the physical state of green open space and the second is the management of organizations associated with the implementation of the Green Open Space. Another management definition proposed that management is what is being done in order to make the green open space preserved, healthy and durable [6]. Based on these definitions, efforts to optimize through management is the management of the physical state of Green Open Space in order to make Green Open Space to be able to provide its ecosystem services optimally.

Optimization of Green Open Space in Urban Areas of Yogyakarta in the perspective of the main ecosystem services can be performed by:

1) Optimization of Urban Forest Ecosystem Services

a. Adding local species such as Sawo Kecik (Manilkara kauki), Sawo bludru/ijo (Chrysopyllum cainito), Mundu (Garcinia dulcis), Kepel (Stelechocarpus burahol), and Gayam (Inocarpus fagiferus)

b. Adding flowering trees in order to enhance the aesthetic ecosystem services in the areas. Like Acacia (Acacia mangium), Angsana (Pterocarpus indicus), Johar (Senna Siamea), Kenanga, and Tanjung (Mimusops elengi). 
c. The presence of tree species with high Pb-absorbing ability and fit the location condition is as follows: Ketapang (Terminalia catappa), Cemara gunung (Casuarina junghuhniana), Angsana (Pterocarpus indicus), Acacia (Acacia auriculiformis), Kupu-kupu (Bauhinia purpurea), Cananga (Canarium odoratum), Mangium (Acacia mangium), and Kiara payung (Filicium decipiens).

d. The addition of facilities such as nameplates for the trees of several types of large trees will also increase cultural ecosystem services of recreation and ecotourism for the area. The presence of the facility such as pergolas in the arboretum can now be enhanced with the application of either polycarbonate roofs in sunlight white or glass with a thickness of $125 \mathrm{~mm}$ so that visitors and observers can still witness the scenery above such as canopy cover and birds roosting and flying above. Pergolas maintenance is also necessary to bolster the functions of the pergola itself.

2) Optimization of Park Ecosystem Services

a. Improve the coverage of groundcover plants. The following grass types can be grown: Oplismenus burmannii (Rumput ekor kucing), Paspalum conjugatum (Rumput pait), Pennisetum purpureum (Rumput gajah mini), and Cynodon Stolon (Rumput jepang).

b. Increasing tree species variety especially in Denggung Park area.

3) Optimization of River Border Ecosystem Services

a. Optimization of Canopy Stratum. The border areas are necessary to propagate vegetation especially local species, species with the high $\mathrm{Pb}$-absorbing ability, rare and endangered species, and species with high water-storing ability in order to generate a multi-strata form within the border area.

b. Coverage of Groundcover Plants. Groundcover plants have a vital role to shield the soil from rain droplets and reduce the amount and speed of runoff as well as increase water infiltration into the soil so as to reduce erosion [7].

c. Facilities. [8] elaborate that riverbanks areas play a role as buffer zones serving purposes to control flood and erosion, to purify water and replenish with groundwater supply as well as to feature recreational and elegance values.

4) Optimization of Ecosystem Service of Road Green Belts

Following are the efforts to be made in order to improve existing functions of ecosystem services:

a. Growing plants with various strata by planting woody plants or decorative plants such as Pucuk merah (Oleina Syzygium).

b. Increasing tree species variety to enhance density and establish multi-strata green belts such as Glodogan tiang (Polyathea Longifolia), Talok/Kersen (Muntingia calabura), Bungur (Lagerstroemia speciosa), and Biola cantik (Ficus lyrata).

\section{Conclusions}

1. Each green open space criterion plays different roles in ecosystem services. Some categories of green open spaces have more significant roles in ecosystem services than others.

2. The quality of ecosystem services in urban Yogyakarta's GOS vary depending on the type of Green Open Spaces. In general, urban forests, including Urban Forest of Arboretum of Faculty of Forestry, Gadjah Mada University, and Arboretum of Gembira Loka Zoo, have the highest quality ecosystem services, while city parks, such as Denggung Park, Gajah Wong Educational Park, and Lalu Lintas Park, and riverbanks, including Code's riverbank, Gajah Wong's riverbank, and Winongo's riverbank, have average quality ecosystem services, and street greenbelts, including Magelang Street, Cik Di Tiro Street and Malioboro Street greenbelts, generally have poor ecosystem services.

3. Optimizing green open space in the Municipal area of Yogyakarta with regards to ecosystem services can be accomplished by:

a. The distribution of ecosystem services can be enhanced by improving the crown density by planting more environmentally beneficial trees such as fruit-bearing trees and water-storing trees.

b. Regulating ecosystem services can be enhanced by increasing the diversity of tree species, especially species with high water-storing capabilities which have a high crown density.

c. Cultural ecosystem services can be increased through the addition of tree varieties such as flowering local, identity, and rare and protected tree species. Those trees can then be stratified to entice animals. Moreover, we can add facilities such as seating, garbage cans, and lights to support the utilization of Green Open Space by the community.

d. Supporting ecosystem services can be improved by adding more trees species which have been planted in stratified layers to improve their overall crown density. 
Acknowledgements The authors would like to thank Badan Penerbit dan Publikasi Universitas Gadjah Mada (BPP UGM) for financially supporting it to be presented in UGM ICTA 2017.

\section{References}

1. Wulandari, L.D., Turniningtyas, A.R., Subhan R.: Hirarki peran ragam ruang terbuka hijau (RTH) dalam peningkatan kualitas ekologis lingkungan pusat Kota Malang [Hierarchy of roles of green open space in the improvement of ecological quality of Malang downtown environment]. [Penelitian Unggulan Perguruan Tinggi]. Universitas Brawijaya (2013). [In Bahasa Indonesia].

2. Jannah, A.: Taman manula sebagai respon kuantitas ruang terbuka. [Elderly parks as a response to open space quantity. Arsitektur, Universitas Brawijaya, Malang. (2009). [In Bahasa Indoensia]. [Online unpublished].

3. Molnar, D.: Anatomy of a park: The essentials of recreation area planning and design. $4^{\text {th }}$ ed, pp. 96. McGraw-Hill Companies, United States (2015).

4. Zulkifli, A.: Dasar-dasar ilmu lingkungan [Basic of environmental science]. pp. 85-86. Salemba Teknika, Jakarta (2014).

5. Jamil, A.B.: A design guide for public park in Malaysia. pp. 5-6. Universiti Teknologi Malaysia, Malaysia (2002)

6. Grey, G.W., Deneke, F.J.: Urban forestry. pp. 35-44. John Wiley and Sons, United States (1986).

7. Baker, F. S., Daniel T. W., Helms, J.: A principles of silviculture. pp. 39-42. Mcgraw-Hill Inc., United States (1979).

8. Gardiner, J. L and Cole, L.: Catchment planning: The way forward for river protection. In P. Boon, (ed.), Proceedings of the International Conference on The Conservation and Management of Rivers, p 397-407. English Nature, New York (1991). [Online unpublished]. 